\title{
A Quantitative Study of Experiences Impacting Music Teacher Development
}

\section{Introduction}

In examining the associations between music and identity, Frith (1996) proposes that rather than music or a performance reflecting the people that make it, music produces the people because it constructs a musical or aesthetic experience that enables people to see themselves in a different way. His argument is premised on two notions: that identity is a 'process not a thing, a becoming not a being'; and that the experience of music is 'best understood as an experience of this self-in-process' (p. 109, emphasis is original). The notion that music participation is an integral part of one's identity finds resonance in other literature by DeNora (2000) and Pitts (2005). It has also been argued that successful music experiences catalyse affective energies that create transformative experiences (DeChaine, 2002; Olson, 2005; Qi \& Veblen, 2016).

This article examines the kinds of experiences - music and non-music - that 'produce' a music teacher and which contribute to their identity as music teachers in Singapore music classrooms. It begins with a survey of literature on music experiences and other kinds of experiences that impact on music teacher identity, and examines the discourse that connects music identity and music teacher identity. It explains the methodology which employed a quantitatively driven questionnaire with inferential statistical analysis. Finally, it discusses types of experiences and their impact on music teaching abilities, as well as the possible associations between experiences, perceived abilities and music teacher pride.

\section{Literature Review}

'Music experience' as a construct has engaged scholars in music and music education (e.g., Barrett \& Webster, 2014; Chin \& Rickard, 2012; DeChaine, 2002; Lamont, 2012; Ruismäki \& Tereska, 2006; Schneider, 2008; Werner, Swope, \& Heide, 2006). Small's (1998) concept of 'musicking', in which 'music is not a thing at all but an activity, something that people do' (p. 2) gives prominence to the embedded experience of the musical action in music learning. There is also an understanding that music learning can occur outside formal contexts, such as in Green's (2002) research on the informal learning practices of popular and rock musicians. However, Pitts' (2012) study of the long-term impact of music education found that there were no clear boundaries between the effects of home and school influences. Folkestad's (2006) review also reminded us of the need to account for non-formal music learning experiences, such as in community settings. Across these contexts, Lum (2008) found that musical identities were 'developed partially through influences of technology and the media, and [that] families defined unique soundscapes in their homes through the negotiation of musical interests within their family members' (p. 113). Such studies suggest that music learning and music experiences intertwine in our musical biographies, and take place across formal, 
informal, and non-formal contexts, collectively making a long-term contribution to personal and collective identities (MacDonald, Hargreaves, \& Miell, 2017).

In seeking to understand more clearly what is meant by 'music experience', music psychology scholars have offered several related perspectives. Brim (1978), for example, conceptualized aesthetic response to music in two domains, the 'emotional-cognitive' and the 'physiological'. Similarly, Werner, Swope and Heide (2006), in analyzing the latent constructs to music experiences, found two factors, 'subjective/physical reactions to music' and 'active involvement'. These have resonance with Chin and Rickard's (2012) Music Use Questionnaire, which sought to profile music experiences and engagement through two segments: the reception and production processes of music.

Also, from music psychology and social-psychology perspectives, there are reported associations between music experiences and perceived music abilities (e.g. Thompson \& Schellenberg, 2006), as well as between music experiences and musical identity (e.g. Lamont, 2002). Schneider (2008), for example, noted that music experience has often been used as a predictor in music achievement research. A noteworthy finding by Randles (2010) was that composition experiences were seen as the strongest predictor of high school students' music self-concept amongst factors that included school music activity, home music activity, satisfaction with school music experience, and perception of personal contribution to learning in the school music setting. This finding suggests that certain aspects of active musical experience are seen as more privileged and significant than others.

The associations between music experiences and music teacher identity have also been explored by various scholars in empirical and sociological discourse (e.g., Ballantyne \& Grootenboer, 2012; Bernard, 2005; Freer \& Bennett, 2012; GeorgiiHemming, 2011; Hargreaves, Purves, Welch, \& Marshall, 2007; Jorgensen, 2008; Welch, Purves, Hargreaves, \& Marshall, 2010). For example, Pellegrino's (2009, 2011, 2015) research examined how past music-making experiences shaped music teachers' beliefs about music-making and how these informed their teaching practices. She drew connections between performer and teacher identities, arguing that music making helped bring participants' personal and professional lives together.

Apart from experiences in music, other experiences can have an impact on music teacher identity. There is an argument that the binary focus on music identity and teacher identity as constructs of music teacher identity is insufficient because there are multiple identities (Beijaard, Meijer, \& Verloop, 2004; Dawe, 2007; Dolloff, 2007; Regelski, 2007; Roberts, 2007). Others have highlighted the essential role of socialization on music teacher identity (e.g. Isbell, 2008, 2015; Kastner, Reese, Pellegrino, \& Russell, 2018). There are also perspectives that music learning ecologies can impact or are impacted by other aspects of a young person's non-musical life (O'Neill, 2017), and that personal biography has a role in teacher identity (Bukor, 2015; Dawe, 2007; Rodgers \& Scott, 2008; Skerrett, 2008). Various frameworks have suggested that music teacher identity is multidimensional, thus extending beyond the influence of music experiences (e.g. McClellan, 2017). 
There are only a few quantitative studies on music teacher identity or discussion of its constructs that could support a psychologically-focused perspective on music teacher development. From general education studies, Kao and Lin (2015) developed six dimensions of teachers' professional identity which included teachers' duties (responsibilities toward students, curriculum content, and society) and external influential factors (such as perceptions of social interactions and school policy). Cheung (2008) measured the professional identity of Hong Kong in-service teachers and reported three latent factors including student needs and school needs, alongside personal growth and development. In seeking to measure music teacher identity, Wagoner (2015) developed a Music Teacher Identity Scale which comprised two constructs: music teacher selfefficacy reliability, and music teacher commitment. Overall, there seems to be a need for more quantitatively-based studies to expand our understanding of how music teacher identity development might move beyond the music and teaching domains as influencers. Hence, the current study intends to fill a gap in our understanding of the development of music teacher identity of in-service music teachers by exploring quantitatively the intersections between music experiences, non-music experiences and perceived teaching abilities.

\section{Methodology}

The literature review above has discussed the likely experiences that shape and support the development of music teachers. With these theoretical underpinnings, the current study investigated the extent to which the different experiences - music and non-music impact on specialist music teachers. It also examined the associations between experiences, perceived (music) teaching abilities and their pride as music teachers. Music experiences refer to teachers' music learning in various formal, informal and non-formal contexts. Types of music experiences include composition, improvising, performing, listening experiences and exposure to different kinds of music.

A questionnaire that was predominantly quantitative in design with both forcedchoice (on a 5-point Likert scale) and open-ended questions was piloted twice - first on hard copy, and later online - to check for validity such as its readability, feasibility, clarity, layout and style. The survey was designed with three sections: (a) music experiences; (b) perceived music abilities and music teaching abilities; and (c) non-music experiences. Participants had to rate each of 52 items on a 5-point Likert scale across the three sections. At the end of the questionnaire, there was an additional question which required participants to rate if they were proud to introduce themselves to others as a music teacher.

The questionnaire was administered online using QuestionPro Survey Software (2017). Invitations were sent to 100 Primary and Secondary schools in Singapore through the Principals with clearance from the Ministry of Education (MOE), Singapore, since the data were collected from MOE teachers. Out of 190 specialist music teachers who taught only music at primary and secondary levels at the point of the study, there were 72 completed responses from specialist music teachers, thus the margin of error is $9 \%$ at 95\% confidence interval. Of the participants, $13.9 \%$ were males and $86.1 \%$ were females. They represented a range of age-groups: $27.8 \%$ were $20-29 ; 27.8 \%$ were $30-39 ; 34.7 \%$ 
were 40-49; 9.7\% were 50-59. The participants also taught different age-groups, with $54.2 \%$ teaching at the Primary level; $45.8 \%$ teaching at the Secondary level. Different numbers of years of experiences in teaching music in schools were also evidenced: $13.9 \%$ were beginning teachers with less than 3 years of experience; $22.2 \%$ teachers had 3-5 years of experience; $20.8 \%$ had 6-10 years of experience; and $43.1 \%$ had more than 10 years of experience. Across the group, $38.8 \%$ of participants were holding leadership positions in their schools, such as being the 'senior teacher', 'subject head' or 'head of department' ${ }^{1} .48 .6 \%$ of participants took charge of music co-curricular activities in their schools, although only $11.1 \%$ reported teaching their co-curricular activities.

There were three types of analyses conducted to investigate the impact of experiences on perceived teaching abilities. First, the descriptive analysis and the paired sample T-test were conducted to compare the mean ratings of the individual variables belonging to 'music experiences' and 'non-music experiences'. Secondly, factor analyses - Exploratory Factor Analysis (EFA) in IBM SPSS Statistics for Windows, Version 22.0 (IBM Corp, 2013) and Confirmatory Factor Analysis (CFA) in IBM SPSS Amos 26 Graphics (Arbuckle, 2019) - were used iteratively to explore the observed variables and their latent constructs which define experiences and music teaching abilities. This approach supports Schmitt's (2011) argument that CFA is often applied in an exploratory manner and EFA could be applied as a follow-up to CFA for further exploration of the model fit. As the number of participants was relatively small (less than 100), it was not appropriate to divide the participant data into two parts to run the EFA and CFA separately for confirmatory purposes. Third, linear regression was then conducted to generate inferences in the relationships between the constructs. Since the study also sought to investigate specific variables in music and non-music experiences that might impact on perceived teaching abilities and music teacher identity, multiple regression and stepwise regression were conducted to observe individual variables (not just constructs) that impacted on perceived teaching abilities and music teacher pride.

\section{Descriptive Analysis and Paired-Sample T-Test}

\section{Type of Music Experiences and Their Impact}

Of the 72 specialist music teachers surveyed, most participants $(88.9 \%)$ agreed or strongly agreed that they felt a strong presence of music in their lives currently. The most common musical involvement reported by music teachers in their current lives was listening to performances outside of school (94.4\%). This was followed by performing in school $(63.9 \%)$, performing in other than school events $(41.7 \%)$, teaching music as a vocal/instrumental tutor outside of school (30.6\%), composing for school events (15.3\%), composing for other than school events $(9.7 \%)$ and teaching music as a community leader (e.g., community choral conductor) $(5.6 \%)$.

${ }^{1}$ Heads of Department in Singapore schools typically hold administrative duties and coordinate the teaching-learning of music and a few other subjects in their schools. They also supervise the teachers in these subject areas. A Subject Head holds a smaller portfolio compared to the Head of Department in that they look after the administrative duties of only one or two subjects. Senior teachers and Lead teachers are appointments for teachers who wish to specialise and grow in their pedagogical leadership of their subject. They do not have as many administrative duties as Heads of Department or Subject Heads. 
Most participants reported a positive impact of listening to or watching music performances $(\mathrm{M}=3.94, \mathrm{SD}=.95)$, music choir/ensemble/orchestra experiences $(\mathrm{M}=3.88$, $\mathrm{SD}=1.28)$, music performing experiences $(\mathrm{M}=3.83, \mathrm{SD}=1.34)$, exposure to different kinds of music $(\mathrm{M}=3.82, \mathrm{SD}=1.01)$, music learning on their own $(\mathrm{M}=3.64, \mathrm{SD}=1.03)$, music experiences with professional musicians $(\mathrm{M}=3.64, \mathrm{SD}, 1.33)$, and music learning with friends $(\mathrm{M}=3.58, \mathrm{SD}=1.03)$. The other music experiences which they reported to have a lesser impact on them (in descending order) were music experiences at university/college, music learning in community contexts, music improvisation experiences, music composition experiences, music experiences in secondary school, music experiences in primary school, and music learning in religious contexts. The details are shown in Table 1.

Table 1: Positive Impact of Music Experiences ( $n=72$ specialist music teachers)

\begin{tabular}{|c|c|c|c|}
\hline & Mean & Mode & $\mathrm{SD}$ \\
\hline Listening to or watching music performance(s) & 3.94 & 4 & .95 \\
\hline Music choir/ensemblelorchestra experiences & 3.88 & 4 & 1.28 \\
\hline Music performing experiences & 3.83 & 4 & 1.34 \\
\hline Exposure to different kinds of music & 3.82 & 4 & 1.01 \\
\hline Music learning on my own & 3.64 & 4 & 1.03 \\
\hline Music experiences with professional musicians & 3.64 & 4 & 1.33 \\
\hline Music learning with friends & 3.58 & 4 & 1.03 \\
\hline Music experiences at university/college & 3.25 & 4 & 1.68 \\
\hline Music learning in community contexts & 3.00 & 4 & 1.46 \\
\hline Music improvisation experiences & 2.82 & 3 & 1.46 \\
\hline Music composition experiences & 2.82 & 3 & 1.33 \\
\hline Music experiences in secondary school & 2.57 & 3 & 1.49 \\
\hline Music experiences in primary school & 2.49 & 2 & 1.36 \\
\hline Music learning in religious contexts & 2.36 & 0 & 1.72 \\
\hline
\end{tabular}

Note: Participants were asked to rate each of the music experiences according to their positive impact on them as music teachers on a 5-point Likert scale (1: Very little impact; 5: Very large impact).

Participants had the option to offer other additional qualitative responses. There were 16 responses, and these were coded thematically. Six participants wrote about a closer interaction with music, such as 'listening, analyze local music composition' and 
'songs that are written with positive messages / inculcate values', reflecting the meaningmaking processes. Four emphasized the interactions with musical others, such as 'musicking with pedagogy experts, artists and music lovers', 'having a family that encourages listening to different types of music', 'being part of a creative team'. Six added comments on teaching and interactions with students, such as 'watching the children's performance after guiding them through the whole process'. Three participants also mentioned travel experiences, such as 'learning journey to another country', 'overseas school visits', and 'musical experience training attachment overseas'. These responses suggested that there were extra-musical associations to the music experiences which created a sufficiently large enough impact to be reported separately in the questionnaire.

\section{Type of Non-music Experiences and Their Impact}

A paired sample t-test was conducted to compare the mean ratings of music and nonmusic experiences. The assumptions of the t-test were met as: a) the dependent variables were continuous, since the ratings were on a Likert scale; b) the participants' reporting for music and non-music experiences were independent of one another; c) outliers were also removed; d) approximate normal distribution was observed in the histogram describing the frequency of mean differences between music and non-music experiences. Findings revealed that non-music experiences $(\mathrm{M}=3.62, \mathrm{SD}=.53)$ were perceived to have a larger positive impact on music teachers compared to their music experiences $(\mathrm{M}=3.44$, $\mathrm{SD}=.56)$, and the difference was significant with a relatively small effect size, $t(66)=$ $2.31, p=.024, d=.28$. The power was $50.4 \%$.

The areas that were perceived to have large positive impact by most teachers, in descending order, included: the positive responses from students; learning of new approaches; working with students; watching other lessons; support by leaders; working with other teachers; experiencing music learning as a student; taking on a new role/responsibility; starting a new programme/ syllabus/ CCA (co-curricular activity); feeling a sense of belonging to the teaching community; mentoring by other teachers; mentoring other teachers; and leading other teachers (see Table 2).

Table 2: Positive Impact of Non-music Experiences ( $n=72$ specialist music teachers)

\begin{tabular}{lccc}
\hline & Mean & Mode & SD \\
\hline Positive responses from students & 4.29 & 4 & .91 \\
\hline Learning new teaching approaches & 4.08 & 4 & .93 \\
\hline Working with students & 4.00 & 4 & .90 \\
\hline $\begin{array}{l}\text { Watching other lessons } \\
\text { Support by leaders }\end{array}$ & 3.93 & 4 & .97 \\
\hline $\begin{array}{l}\text { Working with other teachers e.g. co-teaching, co- } \\
\text { planning }\end{array}$ & 3.75 & 4 & 1.31 \\
\hline
\end{tabular}




\begin{tabular}{lccc}
\hline & Mean & Mode & SD \\
\hline Experiencing music learning as a student & 3.57 & 4 & 1.19 \\
\hline Taking on a new role / responsibility & 3.57 & 4 & 1.11 \\
\hline $\begin{array}{l}\text { Starting a new programme, syllabus, or co-curricular } \\
\text { activity }\end{array}$ & 3.51 & 4 & 1.34 \\
\hline Feeling a sense of belonging to the teaching community & 3.46 & 4 & 1.15 \\
\hline Mentoring by other teachers & 3.42 & 4 & 1.31 \\
\hline Mentoring other teachers & 3.33 & 4 & 1.48 \\
\hline $\begin{array}{l}\text { Leading other teachers } \\
\text { Working with other stakeholders e.g. parents }\end{array}$ & 3.26 & 4 & 1.45 \\
\hline $\begin{array}{l}\text { Teaching experiences outside school } \\
\text { Religious or spiritual influences }\end{array}$ & 2.94 & 3 & 1.14 \\
\hline
\end{tabular}

Note: Participants were asked to rate each of the music experiences according to their positive impact on them as music teachers on a 5-point Likert scale (1: Very little impact; 5: Very large impact).

Participants had the option to offer additional responses and seven commented. Four teachers' comments were directly related to music, pedagogical and school experiences, such as 'reading on music experiences on music teachers' blogs, experts, YouTube', 'positive school culture' and the perceived influence of other disciplines such as 'Science learning experience and practical work'. Three spoke about their experiences outside of their work, such as 'participating in religious activities'. Military experience was mentioned by one respondent as having had a positive impact, since 'important values such as discipline, teamwork ... play an important role in how I want my students to learn music'. These responses shed light on the myriad nature of development and how even seemingly distant and unrelated activities could have impactful development on an individual music teacher.

\section{Factor Analysis}

Factor Analyses were undertaken with both EFA and CFA used iteratively to explore the observed variables and their latent constructs (Schmitt, 2011). Firstly, all the 52 variables in the three sections were tested with EFA using Principal Axis Factoring. The assumptions were tested. The Kaiser-Meyer-Olkin (KMO) measure revealed that the sampling was only mediocre (Kaiser, 1974), $\mathrm{KMO}=.612$, with a significant Bartlett's test of sphericity $\chi^{2}(1326)=3022.875, p=.000 .12$ factors loaded above eigenvalues of 1 , reading $74.98 \%$ of variance. However, the scree plot suggested only one factor. Using parallel analysis (Horn, 1965), a comparison of Factor Analysis and Parallel Analysis 
eigenvalues was conducted; this confirmed five factors which were then retained for interpretation and subsequent analysis. The five factors explained $54.5 \%$ of variance.

Principal Axis Factoring was conducted again, this time extracting five factors. The correlations between factors was in the range of .002 to .024 , which was less than Tabachnick and Fidell's (2007) threshold of .32, suggesting that the factors were orthogonal. Hence, Varimax rotation was applied. Coefficient values less than .32 were suppressed. Items that loaded less than .4 were removed. Cross-loading items with values $\geq .32$ on at least two factors were also deleted where there were other items with factor loadings of .50 or greater (Costello \& Osborne, 2005). Only two items were not removed even though their cross-loadings were $\geq .32$ because these were part of the three items remaining for each of the factors.

CFA was conducted on the above five-factor, 29-item solution. Standardised regression weights were examined. Seven items with standardized regression rates less than .6 were removed. Modification indices were also studied, and covariances were drawn between three pairs of unobserved variables. Based on the threshold measures $(\mathrm{Hu}$ $\&$ Bentler, 1999), the 5-factor, 22-item model found an overall moderate fit, $\chi^{2} / d f=1.400$, $\mathrm{p}=.000, \mathrm{CFI}=.888, \mathrm{RMSEA}=.075$.

The five-factor, 22-item solution was tested again with EFA using Principal Axis Factoring and Varimax rotation. The KMO measure revealed that the sampling was middling (Kaiser, 1974), KMO=.741, and with a significant Bartlett's test of sphericity $\chi^{2}(231)=823.556, p=.000$. The new scree plot pointed to five factors, and these explained $67.624 \%$ of variance. Loadings with coefficients less than .32 were suppressed as before. Two items were with cross-loadings were removed. Only one was kept as this was part of the three-item factor. Running the CFA with the 5-factor, 20-item solution, the results found a slightly improved fit as described in Table 3. Running the EFA once again, the KMO measure was still middling, $\mathrm{KMO}=.734$, and with a significant Bartlett's test of sphericity $\chi^{2}(190)=708.944, p=.000$. The five factors explained $68.719 \%$ of variance. The resulting factor loadings and the model are described in Table 4 and Figure 1 .

Table 3: Comparison of 20-item and 22-item Five-Factor Solution

\begin{tabular}{llllllll}
\hline & $\chi^{2}$ & $d f$ & $\chi^{2} / d f$ & $p$ & NFI & CFI & RMSEA \\
\hline 5-factor (22-item) & 274.416 & 196 & 1.400 & .000 & .705 & .888 & .075 \\
\hline 5-factor (20-item) & 213.017 & 158 & 1.348 & .002 & .771 & .909 & .070 \\
\hline
\end{tabular}

Table 4: Factor Loadings of the Five-factor, 20-item Solution

\begin{tabular}{|c|c|c|c|c|c|c|c|}
\hline \multirow[t]{3}{*}{ Variables } & \multicolumn{6}{|l|}{ EFA 5 Factors } & CFA \\
\hline & Communalities & \multicolumn{5}{|c|}{ Factors } & Standardised \\
\hline & Extraction & 1 & 2 & 3 & 4 & 5 & Weights \\
\hline
\end{tabular}




\begin{tabular}{|c|c|c|c|c|c|c|c|}
\hline $\begin{array}{l}\text { Feeling a sense of belonging to the } \\
\text { teaching community }\end{array}$ & .627 & .760 & & & & & $.770^{\star \star \star}$ \\
\hline Support by leaders & .606 & .758 & & & & & $.751^{\star \star \star}$ \\
\hline $\begin{array}{l}\text { Working with other teachers e.g.co- } \\
\text { teaching, co-planning }\end{array}$ & .598 & .728 & & & & & $.709^{* \star *}$ \\
\hline Taking on a new role responsibility & .522 & .636 & & & & & $.732^{\star \star \star}$ \\
\hline Teaching experiences outside school & .427 & .553 & & & & & $.597^{\star \star \star}$ \\
\hline $\begin{array}{l}\text { To interest most of my students in } \\
\text { music in general }\end{array}$ & .693 & & .810 & & & & $.684^{* * *}$ \\
\hline $\begin{array}{l}\text { To grow the music culture in my } \\
\text { school }\end{array}$ & .723 & & .776 & & & & $.874^{* * *}$ \\
\hline $\begin{array}{l}\text { To facilitate students' music } \\
\text { performance }\end{array}$ & .619 & & .700 & & & & $.768^{\star \star \star}$ \\
\hline $\begin{array}{l}\text { To get most of my students to } \\
\text { appreciate different types of music }\end{array}$ & .455 & & .628 & & & & $.660^{\star \star *}$ \\
\hline To teach a band/choir/ensemble & .493 & & .586 & & & & $.660^{\star \star *}$ \\
\hline $\begin{array}{l}\text { Listening to or watching music } \\
\text { performances }\end{array}$ & .701 & & & .800 & & & $.689^{\star \star \star}$ \\
\hline Exposure to different kinds of music & .641 & & & .771 & & & $.625^{\star \star \star}$ \\
\hline Music learning on my own & .498 & & & .642 & & & $.763^{\star \star \star}$ \\
\hline Music performing experiences & .459 & & & .554 & & & $.706^{* * *}$ \\
\hline Improvising music & .715 & & & & .807 & & $.799^{\star * \star}$ \\
\hline Composing music & .662 & & & & .766 & & $.820^{\star \star *}$ \\
\hline $\begin{array}{l}\text { To facilitate students' music } \\
\text { composition }\end{array}$ & .569 & & .364 & & .618 & & $.708^{\star * *}$ \\
\hline Performing in an ensemble & .761 & & & & & .799 & $.887^{\star \star \star}$ \\
\hline Conducting a music group & .616 & & & & & .743 & $.759^{\star \star \star}$ \\
\hline $\begin{array}{l}\text { Working with pop music repertoire } \\
\text { that is familiar to my students }\end{array}$ & .436 & & .384 & & & .498 & $.581^{* * *}$ \\
\hline
\end{tabular}

${ }^{* * *} P<.001$ 
Figure 1: CFA Model of 5 Factors, 20 items

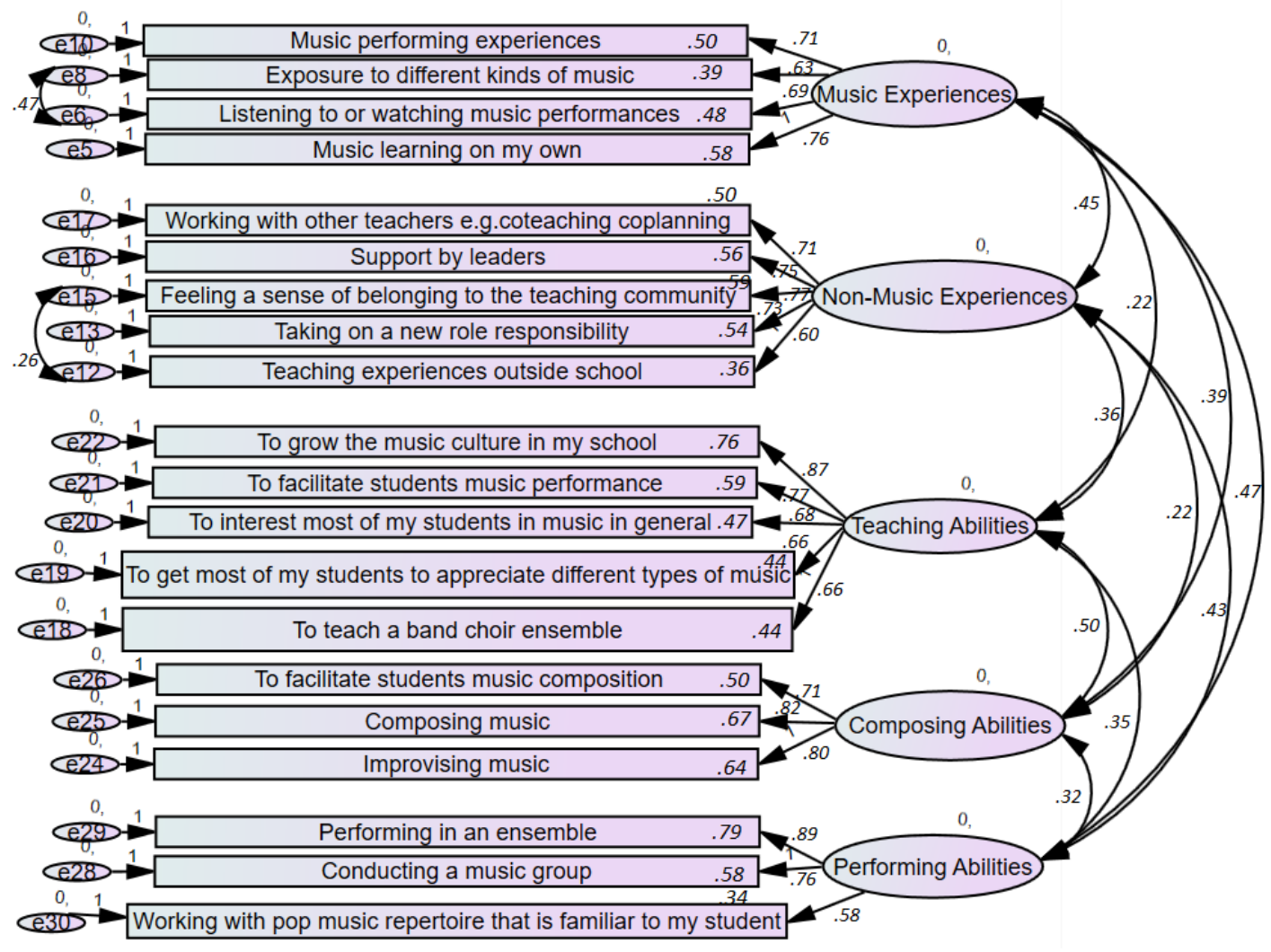

Using the validated variables, the reliability of the questionnaire was then tested with Cronbach's alpha for the scaled items. The various subscales scored highly on the reliability coefficient: music experiences $(N=4, \alpha=.80)$; non-music experiences $(N=5, \alpha$ $=.74)$; perceived teaching abilities $(N=5, \alpha=.85)$; perceived composing abilities $(N=3 ; \alpha$ $=.81)$; and perceived performing abilities $(N=3, \alpha=.78)$.

\section{Linear Regression}

Multiple linear regression was used to examine the extent to which teachers' perceived music teaching abilities was predicted by their music and non-music experiences, and their perceived composition and performing abilities. The independent variables were the constructs 'music experiences', 'teaching abilities', 'composition abilities' and 'performing abilities', which were the aggregate value of the variables validated through the earlier factor analyses, and weighted using the regression weights in CFA. The dependent variable was the aggregate value of the variables using the regression weights in CFA for perceived music teaching abilities validated through the earlier factor analyses. 


\section{Associations Between Experiences and Perceived Music Teaching Abilities}

Multiple regression was conducted to examine associations between perceived teaching abilities and, 'music experiences' and 'non-music experiences'. Preliminary assumption testing was conducted. The histogram and normal probability plot appeared to be normally distributed. The scatterplot was fairly homoscedastic. The Durbin-Watson statistic that was computed to evaluate the independence of errors was 1.98 , which was considered acceptable, and suggested that the assumption of independent errors had been met. The collinearity statistics were examined: tolerance was .602 (greater than .10), and the variance inflation factor was 1.66 (less than 10), suggesting that multicollinearity was not an issue. Hence, overall, no violations were noted.

The results suggest that a significant proportion of perceived teaching abilities was predicted by non-music experiences, $F(1,70)=7.561, p=.008$, with an $R^{2}$ of .097 and adjusted $R^{2}$ of .085 . These non-music experiences represent a composite of variables including 'working with teachers, e.g., co-teaching, co-planning', 'support by leaders', 'feeling a sense of belonging to the teaching community', 'taking on a new role or responsibility', and 'teaching experiences outside school'. The intercept (or average score of perceived teaching abilities when the predictors is 0 ) was 10.43 , statistically significantly different from $0(t=2.750, p=.008)$. Hence, non-music experiences were found to be significantly, positively associated with perceived teaching abilities (Table $5)$.

Table 5: Regression Analysis - Experiences Predicting Perceived Teaching Abilities

\begin{tabular}{llllll}
\hline Significant Variable & $\mathrm{B}$ & $\mathrm{SEB}$ & $\beta$ & $\mathrm{t}$ & $\mathrm{p}$ \\
\hline Non-Music Experiences & .201 & .073 & .312 & 2.750 & .008 \\
\hline
\end{tabular}

The overall model is significant, $R^{2}=.097, R^{2}$ adj $=.085, F(1,70)=7.561, p=.008$

Music experiences, as a variable that represent a composite of variables, on the other hand, was not found to be significantly, positively associated with perceived music teaching abilities. However, with a closer examination of music experiences using stepwise regression, where all the individual variables of music experiences are added as independent variables, it was found that 'music composition experiences' was significantly, positively associated with perceived teaching abilities, $F(1,70)=13.960, p$ $=.000$, with an $R^{2}$ of .166 and adjusted $R^{2}$ of .154 . The intercept (or average score of teacher efficacy when the predictors is 0 ) was 11.081 , statistically significantly different from $0(t=20.232, p=.000)$ (Table 6).

Table 6: Regression Analysis - Variables in 'Music Experiences' Predicting Perceived Teaching Abilities

\begin{tabular}{llllll}
\hline Significant Variables & B & SE B & $\beta$ & t & p \\
\hline Music composition experiences & .658 & .176 & .408 & 3.736 & .000 \\
\hline
\end{tabular}

The overall model is significant, $R^{2}=.166, R^{2}{ }_{\text {adj }}=.154, F(1,70)=13.960, p=.000$ 
Associations between Perceived Composing and Performing Abilities with Perceived Teaching Abilities

Multiple regression was also conducted for the constructs 'perceived composition abilities' and 'perceived performing abilities' as independent variables. The assumptions were examined. The histogram and normal probability plot appeared to be normally distributed. The scatterplot was fairly homoscedastic. The Durbin-Watson statistic computed to evaluate the independence of errors was 1.96, which suggested that the assumption of independent errors had been met. The collinearity statistics were examined and there were no multicollinearity. Hence, overall, no violations were noted.

The results suggest that a significant proportion of perceived teaching abilities was predicted by perceived composing abilities and performing abilities, $F(2,69)=$ $11.498, p=.000$, with an $R^{2}$ of .250 and adjusted $R^{2}$ of .228 . The intercept (or average score of perceived teaching abilities when the predictors is 0 ) was 7.11 , statistically significantly different from $0(t=5.573, p=.000)$. The predictor variables that were statistically significant are reported in Table 7.

Table 7: Regression Analysis - Constructs Predicting Perceived Teacher Abilities

\begin{tabular}{llllll}
\hline Significant Constructs & B & SE B & $\beta$ & t & p \\
\hline Perceived Composing Abilities & .396 & .128 & .337 & 3.103 & .003 \\
\hline Perceived Performing Abilities & .414 & .157 & .287 & 2.645 & .010 \\
\hline
\end{tabular}

The overall model is significant, $R^{2}=.250, R^{2}{ }_{\text {adj }}=.228, F(2,69)=11.498, p=.000$

From a closer examination using stepwise regression where all the individual variables of perceived composing and performing abilities were added as independent variables, it was found that of these variables, 'to facilitate students' music composition' and 'working with pop music repertoire that is familiar to my students' were significantly, positively associated with perceived teaching abilities, $F(2,69)=19.863, p$ $=.000$, with an $R^{2}$ of .365 and adjusted $R^{2}$ of .347 . The intercept (or average score of teacher efficacy when the predictors is 0 ) was 5.611 , statistically significantly different from $0(t=4.740, p=.000)$. The details are in Table 8 .

Table 8: Regression Analysis - Variables in 'Perceived Composing Abilities' and 'Perceived Performing Abilities' Predicting Perceived Teaching Abilities

\begin{tabular}{llllll}
\hline Significant Variables & B & SE B & $\beta$ & t & p \\
\hline $\begin{array}{l}\text { To facilitate students' music } \\
\text { composition }\end{array}$ & 1.102 & .266 & .402 & 4.148 & .000 \\
\hline $\begin{array}{l}\text { Working with pop music repertoire } \\
\text { that is familiar to my students }\end{array}$ & 1.145 & .278 & .399 & 4.116 & .000 \\
\hline
\end{tabular}

The overall model is significant, $R^{2}=.365 R^{2}$ adj $=.347, F(2,69)=19.863 p=.000$ 
The assumptions were checked. The histogram and normal probability plot appeared to be normally distributed. The scatterplot was homoscedastic. The Durbin-Watson statistic was computed to evaluate the independence of errors was 2.02 which was considered acceptable which suggested that the assumption of independent errors had been met. The collinearity statistics were examined: tolerance was .980 for both variables (greater than .10), and the variance inflation factor was 1.020 for both variables (less than 10), suggesting that multicollinearity was not an issue. Hence, overall, no violations were noted.

\section{Associations between Experiences, Perceived Abilities and Music Teacher Pride}

Stepwise regression was also conducted for the constructs 'music experiences', 'nonmusic experiences', 'perceived teaching abilities', 'perceived composition abilities' and 'perceived performing abilities' as independent variables to examine the extent to which these were associated with the participants' reported 'pride' as music teachers.

The assumptions were examined. The histogram and normal probability plot appeared to be normally distributed. The scatterplot was fairly homoscedastic. The Durbin-Watson statistic computed to evaluate the independence of errors was 1.93, which suggested that the assumption of independent errors had been met. The collinearity statistics were examined and there were no multicollinearity. Hence, overall, no violations were noted.

The results suggest that a significant proportion of participants' sense of pride in being a music teacher was predicted by both perceived music and non-music experiences, $F(2,69)=25.574, p=.000$, with an $R^{2}$ of .426 and adjusted $R^{2}$ of .409 . The intercept (or average score of music teacher pride when the predictors is 0 was 1.227 , statistically significantly different from $0(t=2.992, p=.004)$. The predictor variables that were statistically significant are reported in Table 9.

Table 9: Regression Analysis - Constructs Predicting Music Teacher Pride

\begin{tabular}{llllll}
\hline Significant Constructs & $\mathrm{B}$ & $\mathrm{SEB}$ & $\beta$ & $\mathrm{t}$ & $\mathrm{p}$ \\
\hline Music Experiences & .158 & .048 & .387 & 3.293 & .002 \\
\hline Non-music Experiences & .094 & .033 & .335 & 2.851 & .006 \\
\hline
\end{tabular}

The overall model is significant, $R^{2}=.426, R^{2}$ adj $=.409, F(2,69)=25.574, p=.000$

Individual variables for perceived teaching abilities, performing and composing abilities were also set as independent variables. The results suggest that a significant proportion of teacher pride was predicted by their percieved ability to perform publicly and to interest their students in music, $F(2,69)=12.188, p=.000$ with an $R^{2}$ of .261 and adjusted $R^{2}$ of .240 . The intercept (or average score of music teacher pride when the predictors is 0 was $1.147, t=1.831 p=.071$. The predictor variables that are statistically significant are reported in Table 10 below. 
Table 10: Regression Analysis - Variables Predicting Music Teacher Pride

\begin{tabular}{llllll}
\hline Significant Variables & B & SE B & $\beta$ & $\mathrm{t}$ & $\mathrm{p}$ \\
\hline Performing publicly & .389 & .111 & .370 & 3.513 & .001 \\
\hline $\begin{array}{l}\text { To interest most of my students in } \\
\text { music in general }\end{array}$ & .394 & .143 & .290 & 2.753 & .008 \\
\hline
\end{tabular}

The overall model is significant, $R^{2}=.261, R^{2}$ adj $=.240, F(2,69)=12.188, p=.000$

The assumptions were checked. The histogram and normal probability plot appeared to be normally distributed. The scatterplot was homoscedastic. The DurbinWatson statistic computed to evaluate the independence of errors was 1.50 , which was considered acceptable and which suggested that the assumption of independent errors had been met. The collinearity statistics was examined: tolerance was greater than $.10(.965$ for both variables), and the variance inflation factor was less than 10 (1.036 for both variables), suggesting that multicollinearity was not an issue. Hence, overall, no violations were noted.

\section{Discussion}

The questionnaire study sought to understand: a) the impact of music and non-music experiences on specialist music teachers; and $b$ ) the associations between experiences, perceived teaching abilities and their pride as music teachers in the context of Singapore schools. The findings above are discussed below.

Firstly, although participation in music is integral to our daily lives (DeNora, 2000; Pitts, 2005), it is notable that such participation in music would not necessarily be consciously felt by music teachers. Whilst most music teachers (88.9\%) felt a strong presence of music in their lives, it was also observed that some teachers (11.1\%) did not report this. From the descriptive analysis, we also found that most teachers reported a positive impact from listening to or watching performances, performing, and music learning experiences. The mean ratings suggested a lesser impact from experiences at school or university/college, community and religious contexts. This implies that an active involvement in music was perceived to be more impactful than the contexts where activities were experienced. The qualitative responses also suggest that the impact of such music experiences was related to the extra-musical associations made by the teachers themselves.

Secondly, it is also notable that the average mean ratings for non-music experiences $(\mathrm{M}=3.62, \mathrm{SD}=.53)$ were perceived to have a larger positive impact in general on music teachers compared to their music experiences $(\mathrm{M}=3.44, \mathrm{SD}=.56)$, and the difference was significant, but with a small effect size, $t(66)=2.31, p=.024, d=.28$ (the power was $50.4 \%$ ). The areas that were perceived to have the largest positive impact were the experiences with students and the learning of new teaching approaches.

Interactions with others, such as watching other lessons, support by leaders, working with other teachers were also found to have considerable impact. The qualitative comments 
also suggested that development has a myriad nature and that seemingly unrelated events could have impactful development for an individual music teacher. The results also suggest that other non-music aspects of a music teacher's life, especially their work with their students and with others, make an important contribution to their sense of pride as music teachers. Collectively, these findings support a notion of teacher identity development as being more complex than posited in some of the earlier literature.

Thirdly, the factor analyses revealed a relationship amongst music experiences, non-music experiences, teaching abilities, composing abilities and performing abilities. It is noteworthy that the original questionnaire design of perceived music abilities led to two latent factors of perceived composing and performing abilities, suggesting that these were experienced as separate music abilities. The two factors of music abilities composing and performing abilities - add another perspective to the ways in which music experiences have been defined in literature. From the factor analyses, the variables that defined the constructs are summarized as follows.

- The variables that constituted music experiences were 'music performing experiences', 'exposure to different kinds of music', 'listening to or watching music performances' and 'music learning on my own'. Most of these variables were similar to the variables in the descriptive analysis that were found to be impactful on the music teachers.

- The variables that constitute non-music experiences were 'working with other teachers, e.g., co-teaching, co-planning', 'support by leaders', 'feeling a sense of belonging to the teaching community', 'taking on a new role responsibility' and 'teaching experiences outside school'. These relate to teachers' teaching environment and contexts in which they operate.

- The variables that constitute perceived teaching abilities were 'to grow the music culture in my school', 'to facilitate students' music performance', 'to interest most of my students in music in general', 'to get most of my students to appreciate different types of music', and 'to teach a band/choir/ensemble'. These defined teaching abilities as going beyond the teaching actions within the music classroom.

- The variables that constitute perceived composing abilities were 'to facilitate students' music composition', 'composing music' and 'improvising music'.

- The variables that constitute perceived performing abilities were 'performing in an ensemble', 'conducting a music group', and 'working with pop music repertoire that is familiar to my students'.

Fourthly, in considering the constructs that might impact on teachers' perceived teaching abilities, it is notable that 'non-music experience' rather than 'music experience' was a significant predictor. Since the non-music experience is defined by items relating to the contexts and environment which teachers operate, it suggests that these areas significantly influence teachers' perceived teaching abilities. Certainly, 'perceived 
composing abilities' and 'perceived performing abilities' were also significant predictors of teachers' perceived teaching abilities. In addition, amongst the variables in music experiences, 'music composition experiences' was revealed as the significant predictor. The ability to facilitate students' music composition also emerged as a significant predictor of perceived teaching abilities. The prominence of music composition as having an important impact on music teachers echoes Randles' (2010) finding that composition experiences were the strongest predictor of music self-concept.

Fifthly, it is also noteworthy that both constructs 'music experiences' and 'nonmusic experiences' are important predictors of the pride that music teachers feel about themselves as music teachers. It also seems that, whilst music composition experiences are positively associated with teachers' own perceptions of their music teaching ability, it is their ability to perform publicly (rather than compositional ability) and their ability to interest students in music which appear to predict their sense of music teacher pride. This finding resonates with literature associating performing identities with music teacher identities (Pellegrino, 2009, 2011, 2015).

\section{Limitations and Future Study}

The findings of this questionnaire study represent only a snapshot of music teacher identity at the point of administration and as represented by the respondents who participated in the context of Singapore. Such a study, when conducted in another context, might yield different results. Future studies could confirm the constructs laid out as exploratory in this study, and could investigate the associations between music experiences and perceived music abilities on perceived teaching abilities with a larger sample size to improve the KMO and model fit.

This study dichotomized experiences in music and non-music for the purpose of the quantitative study. It should be highlighted that non-music experiences open up a myriad of possibilities in terms of their constitution and definition. For example, these could reflect pedagogical experiences, experiences in the wider social and cultural worlds, and experiences with home support, amongst others. Future work might also expand on the impact on these varied experiences on what counts as music teacher growth.

\section{Conclusion}

The findings of this questionnaire study provide a broad overview of music teachers' experiences, their perceived abilities in music and music teaching, the perceived impact of different non-music experiences. It also revealed the associations of these with their perceived music teaching abilities and music teacher pride. There are significant and positive association between perceived composing and performing abilities and perceived music teaching abilities. There are also positive associations between experiences (music and non-music) and music teacher pride. These positive associations highlight the need for music teachers to be continually supported with opportunities such as to develop their confidence in music composing and performing. In addition, music teachers could be supported in ways that can help them engage positively with the contexts and 
environment they operate. This implies that the development of music teachers should not just be focused on functional aspects, such as musicianship and pedagogy, but should also be relate to their musical selves, their personal selves and in their respective social contexts.

In conclusion, the data suggest that there is a need to appreciate the multifaceted influences on the music teacher, and to acknowledge the intertwining of music and nonmusic influences on teachers' perceived music teaching abilities and on the growth of music teachers. Therefore, the professional development of serving music teachers should look beyond their competency development to facilitating and supporting a more holistic consideration of music teacher identities.

\section{References}

Arbuckle, J.L. (2019). Amos (version 26) [Computer Program]. Chicago: IBM SPSS

Ballantyne, J., \& Grootenboer, P. (2012). Exploring relationships between teacher identities and disciplinarity. International Journal of Music Education, 30(4), 368381. https://doi.org/10.1177/0255761412459165

Barrett, J. R., \& Webster, P. R. (Eds.). (2014). The Musical Experience: Rethinking Music Teaching and Learning (1st edition). New York: Oxford University Press.

Beijaard, D., Meijer, P. C., \& Verloop, N. (2004). Reconsidering research on teachers' professional identity. Teaching and Teacher Education, 20(2), 107-128. https://doi.org/10.1016/j.tate.2003.07.001

Bernard, R. (2005). Making Music, Making Selves: A Call for Reframing Music Teacher Education. Action, Criticism, and Theory for Music Education, 4(2), 36pp.

Brim, R. (1978). The effect of personality variables, dogmatism and repressionsensitization upon response to music. Journal of Music Therapy, 15(2), 74-87. https://doi.org/10.1093/jmt/15.2.74

Bukor, E. (2015). Exploring teacher identity from a holistic perspective: reconstructing and reconnecting personal and professional selves. Teachers and Teaching, 21(3), 305-327. 
Cheung, H. Y. (2008). Measuring the professional identity of Hong Kong in-service teachers. Journal of In-Service Education, 34(3), 375-390.

https://doi.org/10.1080/13674580802003060

Chin, T., \& Rickard, N. S. (2012). The Music USE (MUSE) Questionnaire: An Instrument to Measure Engagement in Music. Music Perception: An Interdisciplinary Journal, 29(4), 429-446. https://doi.org/10.1525/mp.2012.29.4.429

Dawe, N. (2007). Identity and borderland discourse: Bridging the personal and the professional in music teacher identity research. The Canadian Music Educator, 49(2), 39-42.

DeChaine, D. R. (2002). Affect and embodied understanding in musical experience. Text and Performance Quarterly, 22(2), 79-98. https://doi.org/10.1080/10462930216609

DeNora, T. (2000). Music in Everyday Life. Cambridge University Press.

Dolloff, L.A. (2007). 'All the Things We Are' : Balancing our multiple identities in music teaching. Action, Criticism, and Theory for Music Education, 6(2), 1-21.

Folkestad, G. (2006). Formal and informal learning situations or practices vs formal and informal ways of learning. British Journal of Music Education, 23(2), 135-145. https://doi.org/10.1017/S0265051706006887

Freer, P. K., \& Bennett, D. (2012). Developing musical and educational identities in university music students. Music Education Research, 14(3), 265-284. https://doi.org/10.1080/14613808.2012.712507

Frith, S. (1996). Music and Identity. In Questions of Cultural Identity (pp. 108-128). SAGE Publications.

Georgii-Hemming, E. (2011). Shaping a music teacher identity in Sweden. In L. Green, Learning, teaching, and musical identity: voices across cultures (pp. 197-209). Bloomington: Indiana University Press. 
Green, L. (2002). How Popular Musicians Learn: A Way Ahead for Music Education. Ashgate Publishing, Ltd.

Hargreaves, D. J., Purves, R. M., Welch, G. F., \& Marshall, N. A. (2007). Developing identities and attitudes in musicians and classroom music teachers. British Journal of Educational Psychology, 77(3), 665-682.

IBM Corp. (2013). IBM SPSS Statistics for Windows (Version 22.0). Armonk, NY: IBM Corp.

Isbell, D. S. (2008). Musicians and Teachers: The Socialization and Occupational Identity of Preservice Music Teachers. Journal of Research in Music Education, 56(2), 162-178. https://doi.org/10.1177/0022429408322853

Isbell, D. S. (2015). The Socialization of Music Teachers: A Review of the Literature. Update: Applications of Research in Music Education, 34(1), 5-12. https://doi.org/10.1177/8755123314547912

Jorgensen, E. R. (2008). The Art of Teaching Music. Bloomington: Indian University Press.

Kaiser, H. F. (1974). An index of factorial simplicity. Psychometrika, 39(1). 31-35.

Kao, Y., \& Lin, S. (2015). Constructing a structural model of teachers' professional identity. Asian Journal of Management Sciences \& Education, 4(1), 69-81.

Kastner, J. D., Reese, J., Pellegrino, K., \& Russell, H. A. (2018). The roller coaster ride: Our music teacher educator identity development. Research Studies in Music Education. https://doi.org/10.1177/1321103X18773114

Lamont, A. (2002). Musical identities and the school environment. In R. A. R. MacDonald, D. J. Hargreaves, \& D. Miell, Musical Identities. Oxford: Oxford University Press. 
Lamont, A. (2012). Emotion, engagement and meaning in strong experiences of music performance. Psychology of Music, 40(5), 574-594. https://doi.org/10.1177/0305735612448510

Lum, C.H. (2008). Home Musical Environment of Children in Singapore: On Globalization, Technology, and Media. Journal of Research in Music Education, 56(2), 101-117. https://doi.org/10.1177/0022429408317517

MacDonald, R., Hargreaves, D. J., \& Miell, D. (Eds.). (2017). Handbook of Musical Identities. Oxford, New York: Oxford University Press.

McClellan, E. (2017). A Social-Cognitive Theoretical Framework for examining music teacher identity. Action, Criticism, and Theory for Music Education, 16(2), 65-101. doi:10.22176/act16.2.65

Olson, K. (2005). Music for community education and emancipatory learning. New Directions for Adult and Continuing Education, 2005(107), 55-64. https://doi.org/10.1002/ace.189

O’Neill, S. A. (2017). Young People's Musical Lives. In R. A. MacDonald, D. J. Hargreaves, \& D. Miell, Handbook of Musical Identities (pp. 79-104). Oxford: Oxford University Press.

Pellegrino, K. (2009). Connections Between Performer and Teacher Identities in Music Teachers: Setting an Agenda for Research. Journal of Music Teacher Education, 19(1), 39-55. https://doi.org/10.1177/1057083709343908

Pellegrino, K. (2011). Exploring the Benefits of Music-Making as Professional Development for Music Teachers. Arts Education Policy Review, 112(2), 79-88. https://doi.org/10.1080/10632913.2011.546694

Pellegrino, K. (2015). Becoming music-making music teachers: Connecting music making, identity, wellbeing, and teaching for four student teachers. Research Studies in Music Education, 37(2), 175-194. https://doi.org/10.1177/1321103X15589336 
Pitts, S. (2005). Valuing Musical Participation: Case Studies of Music Identity and Belonging (1st edition). Aldershot, Hants, England; Burlington, VT: Routledge.

Pitts, S. (2012). Chances and Choices: Exploring the Impact of Music Education (1st edition). New York: Oxford University Press.

Qi, N., \& Veblen, K. K. (2016). Transformative learning through music: Case studies from Brazil. Action, Criticism, and Theory for Music Education, 15(2), 101-125.

QuestionPro Survey Software. (2017). Retrieved from https://www.questionpro.com/

Randles, C. (2010). The Relationship of Compositional Experiences of High School Instrumentalists to Music Self-Concept. Bulletin of the Council for Research in Music Education, 184, 9-20.

Regelski, T. A. (2007). 'Music Teacher' - meaning and practice, identity and position. Action, Criticism, and Theory for Music Education, 6(2), 1-35.

Roberts, B. A. (2007). Music making, making selves, making it right: A counterpoint to Rhoda Bernard. Action, Criticism, and Theory for Music Education, 6(2), 1-13.

Rodgers, C. R., \& Scott, K. H. (2008). The development of the personal self and professional identity in learning to teach. Handbook of research on teacher education, 732-755.

Ruismäki, H., \& Tereska, T. (2006). Early childhood musical experiences: Contributing to pre-service elementary teachers's self-concept in music and success in music education (during student age). European Early Childhood Education Research Journal, 14(1), 113-130. https://doi.org/10.1080/13502930685209841

Schmitt, T.A. (2011). Current methodological considerations in exploratory and confirmatory analysis. Journal of Psychoeducational Assessment, 29, 304. DOI: $10.1177 / 0734282911406653$ 
Schneider, C. (2008). An Investigation and Identification of a Construct of Music Experience. Bulletin of the Council for Research in Music Education, 176, 63-75.

Skerrett, A. (2008). Biography, identity, and inquiry: The making of teacher, teacher educator, and researcher. Studying Teacher Education, 4(2), 143-156.

Small, C. (1998). Musicking: The Meanings of Performing and Listening. Wesleyan University Press.

Tabachnick, B. G., \& Fidell, L. S. (2007). Using multivariate statistics, 5th ed. Boston, MA: Allyn \& Bacon/Pearson Education.

Thompson, W. F., \& Schellenberg, E. G. (2006). The Development of Musical Abilities. MENC Handbook of Musical Cognition and Development, 124-164. https://doi.org/10.1093/acprof:oso/9780195304565.003.0005

Wagoner, C. L. (2015). Measuring Music Teacher Identity: Self-Efficacy and Commitment Among Music Teachers. Bulletin of the Council for Research in Music Education, 205, 27-49. https://doi.org/10.5406/bulcouresmusedu.205.0027

Welch, G. F., Purves, R., Hargreaves, D. J., \& Marshall, N. (2010). Reflections on the “Teacher Identities in Music Education" [TIME] Project. Action, Criticism, and Theory for Music Education, 9(2), 11-32.

Werner, P. D., Swope, A. J., \& Heide, F. J. (2006). The Music Experience Questionnaire: Development and Correlates. The Journal of Psychology, 140(4), 329-345. https://doi.org/10.3200/JRLP.140.4.329-345 